\title{
SÖZLEŞME KURMA ZORUNLULUĞU
}

\author{
Dr. Hasan AYRANCI
}

\section{GÍRIŞ}

Türk Borçlar Hukukunda hakim olan ilke sözleşme özgürlüğüdür. Bu özgürlük kişilerin kuracakları sözleşme ilişkilerini, sınırlarına uymak kaydı ile, diledikleri gibi düzenleme yetkisi tanmaktadı. Bu haliyle Anayasamızda yerini bulan kişinin maddi ve manevi varlığını geliştirme özgürlügüünün bir ifadesidir.

Sözleşme özgürlüğ̈ü çeşitli anlamlarda kullanılmaktadır. Sözleşmeyi yapma, sözleşmenin karşı tarafını seçme, sözleşmenin içeriğini düzenleme, sözleşmenin içeriğini değiştirme, sözleşmeyi ortadan kaldırma ve nihayet sözleşmenin tabi olacağı şekli belirleme belli başlı sözleşme özgürlüğï halleri içermektedir.

Taraflar bu özgürlüğü kullanırken Borçlar Kanununun 19 ve 20'nci maddelerinde yer alan hukuka, ahlaka ve kamu düzenine aykırılık ile sözleşmenin konusunun imkânsız olmamasına dikkat etmelidir. Ayrıca kişilik hakkına aykırı sözleşme yapılamayacağından bu şekilde kurulan sözleşmeler geçersiz olacaktır.

Sözleşme özgürliugü 19.YüzyI ekonomik ve felsefi liberalizm anlayışının bìr ürünüdür. Ancak I. ve II. Dünya Savaşlarının meydana getirdiği etkiler sözleşme özgürlügüünün kapsam ve niteliği hakkında farklı düşüncelerin ortaya çıkmasına yol açmışttr. Polis devletinden hukuk devleti ve sosyal devlet anlayışına geçilmesi nedeniyle sözleşme özgürlü̈̆̈i yeniden değerlendirilmiştir.

\footnotetext{
• Ankara Üniversitesi Hukuk Fakültesi Medeni Hukuk Anabilim Dalı Öğretim Üyesi.
} 
Ekonomik gelişmeler ve devletin niteliklerinin değişmesi, devletlerin çeşitli alanlarda eskisine göre farklı tavır almalarına sebebiyet vermiştir. Bunun sonucu olarak devletin paraya, servet ve mal mubadelesine, iş piyasasma herhangi bir etkide bulunmaksızm hareketsiz durması imkansız hale gelmiştir'.

Sözleşme serbestisine eskisinden farklı açılardan bakılmasının diğer bir sebebi, sanayileşme, nüfus artışı, mal ve bilgi ulaşınının artması, iç ve dış güvenlik ihtiyaçları, savaş dönemi ve yakın savaş tehlikeși ile seferberlik hallerinde özel düzenlemelere ve bakış açılarına olan ihtiyaçtır². Bunun dışında sosyal hayatta meydana gelen değişimler özel hukuku ve buna bă̆lı olarak irade serbestisi prensibini etkilemekte ve dönüştürmektedir.

Sözleşme kurma zorunluluğu piyasada hakim durumda bulunan teşebbüsler ile organize menfaat gurupları bakımından büyük önem arz etmektedir. Bu tür kişi veya kişiler topluluğu karşısinda sözleşme kurmak isteyenler, çerçeve anlaşmaları, toplu sözleşmeler ve genel işlem şartları içeren sözleşmelerle iradelerini sôzleşmeye tam olarak yansitamamakta, kendi dışındą belirlenen sözleşmelere sadece rızasını beyan edebilmektedir ${ }^{3}$.

Bu nedenlerle sözleşme kurma özgürlügünün istisnaları sürekli olarak artmaktadır. Bu istisnaların en önemlisi sözleşme kurma mecburiyetidir (Kontrahierungszwang-Kontrahierungspflicht). Konumuz bakımından sözleşme kurma serbestisinin istisnası olan "sözleşmenin karşı tarafını seçme özgürlüğü” ilkesi akit yapma zorunluluğu ile sinırlanmaktadır.

\section{Sözleşme Kurma Zorunluluğunun Tanımı}

Sözleşme kurma zorunluluğuna ilişkin pek çok tanım yapılmıştır. Örneğin bir tanımlamaya göre, sözleşme kurma zorunluluğu bir kişinin talep etmesi halinde piyasada hakim durumda bulunan kişinin istenen sözleşmeyi kurması yükümlülưğïnù ifade eder ${ }^{4}$. Sözleşmenin kurulması talebinde bulunan kişi hak sahibi konumunda iken, bu talebin muhatabı yúkümlü konumundadır.

' Kilian, 49-50).

¿Kilian. 50

${ }^{3}$ Kilian, 50 .

+ Gauch/Schluep/Jäggi, 1, N.1102; Kramer, Art.19-20 N.94: Rekabet Kurulunun 21.12.2000 tarih ve 00-50/533-295 sayılı kararında "satış yapma zorumluluğu" tabiri kulianılmakitadır. 
Nipperdey'e göre" "sözleşme kurma zorunluluğu hukuk düzeninde yer alan bir norm nedeniyle hukuk süjesinin irade beyanı olmaksızın diğer sözleşme tarafının yararına veya bu sözleşmeye taraf olmayan biri tarafından belirlenen muhteva ile bir sözleşme kurma yükümlülüğỉdür”.

Kilian'a göre ${ }^{6}$, kişi bakımından önemli mal ve hizmetler hakkında kurulacak sözleşmede hak sahibi bakımından beklenen bir hareket tarzının (diğer bir ifadeyle sözleşmenin kurulması talebinin kabulünün) piyasa şartları nedeniyle kabul edilmemesi halinde bu olumsuz durumu düzelten bir araçtır.

Larenz'e göre ${ }^{7}$, bir tarafın, diğer tarafı talebi üzerine belirli muhtevada bir sözleşme kurmakla yïkümlü olmasıdır.

Schönenberger/Jäggi'ye göre ${ }^{8}$, kendisiyle sözleşme kurulmak istenen tarafın belirli bir kişiye karşı var olan, bu kişi ile belli bir yaşam ilişkisinin sözleşme konusu yapılmasına ilişkin yükümlüllüğüdürr".

Sözleşme kurma zorunluluğunun bulunduğu hallerde, ya yükümlü kendisi ile kurulmak istenen bir sözleşmeyi reddedememekte, ya da sözleşmenin muhtevasını dilediği gibi düzenleyememektedir.

Yükümlünün sözleşmenin muhtevasının dilediği gibi düzenleyememesi çeşitli açllardan önem arzetmektedir. Sözleşme kurma zorunluluğunun bulunduğu hallerde sözleşmenin muhtevası taraflarca istenildiği şekilde belirlenecek olursa, yükümlii taraf kurulacak sözleşmeye tamamen kendi lehine olan hükümler koyabilir. Bu durumda sözleşme kurma zorunluluğu ile sözleşme kurmak isteyen tarafa sağlanmak istenen durum gerçekleştirilemez. Çünkü hak sahibi tarafın kendi lehine olan hükümlerin sözleşmede yer alması talebi karşı tarafça reddedilebilecektir. Öneğin sözleşmeye fesih hakkının konması ve bir süre sonra bu hakkın kullanılması sözleşme kurma zorunluluğunu anlamsız kılabilecektir. O halde sözleşme kurma zorunluluğu

${ }^{5}$ Nipperdey, 7 dn.2 Nipperdey, Kontrahierungszwang und diktiertem Vertrag. Jena 1920 (Kilian. 52, dn.22'den naklen).

"Kilian. 52.

${ }^{7}$ Larenz, 42.

${ }^{\text {} S c h o ̈ n e n b e r g e r J J a ̈ g g i, ~ A r t .] ~ N .528 . ~}$

${ }^{9}$ Schönenberger/Jäggi, Art.1 N.528. 
bu açıdan kanun tarafından belirlenmiş veya uygun şartlar altmnda kurulan bir sözleşme yükümlülìğünü ifade etmektedir ${ }^{10}$.

\section{Sözleşme Kurma Zorunluluğunu Doğuran Sebepler}

Sözleşme kurma zorunluluğu yüzyıla yakın bir süre hakim olan sözleşme özgürlị̈̆üu/sözleşmenin karşı tarafını seçme özgürlüğünü sınırlamaktadır. Bu sınırlamanın sebebi ve hangi ihtiyaçları karşıladığı değerlendirilmelidir.

İlk olarak değerlendirilmesi gereken husus yukarıda kısmen söz edildiği üzere sözleşme anlayışımın gelişmesidir. Roma Hukukunun modern hukuk üzerinde bulunan etkisinin azalması ile eskisinden farklı olarak sözleşne şekli kurallardan büyiuk ölçüde arınmıştır. Bunun sonucu olarak kişiler kendi intiyaç ve tasavvurlarına göre ilişkilerini geliștirmiş, buna bağlı olarak da yeni ve muhtevası farklı sözleşmeler ortaya çıkmıştır.

19. Yüzyıldan 20. Yüzyıla geçişte sözleşmelerin temelini oluşturan iradenin oluşumuna ve sözleşme kurmak isteyenlerin karşılıklı duruşlarına ilişkin taraf pozisyonları de ģş̧miş: irade oluşumu ve sözleşmenin kuruluşu gibi olgular kişiler ủstü bir seviyede teşekkül etmeye başlamıştır. Artık ticari şirketler, sendikalar, üst birlikler vb. normal bir hukuk öznesine göre daha farklı bir gücü elinde bulundurmaktadır. Bunun dışında toplu sözleşmelerin. çerçeve anlaşmalarının, hizmet temini şartlarının, genel işlem şartlarının bulunduğu hukuk alanında kişiye has irade beyanının yapısı ve niteliği değişmiştir"

Bunlaron dışında geniş ölçüde edim ilişkileri tarafların açık irade beyanına ihtiyaç olmaksızın doğmaktadır. Özellikle fiili sözleşme ilişkilerinde, sözleşme öncesi görüşmelerde vb. de bu özellik görülmektedir. Ayrıca sözleşme kurmak için alternatiflerin bulunmadığı bir alanda sözleşme kurma zorunluluğu karşımıza çıkmaktadır ${ }^{\prime 2}$.

Sözleşme kurma zorunluluğunun kabul edilme nedenlerinden biri, serbest piyasa ekonomisinde taraflardan birinin gücünü kötüye kullanmasını

"Kilian. 77: Schönenber/Jiggi, Art.I N.540; Merz, N.279; Ritgen, I19: Kramer.

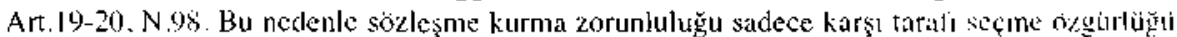
ile değil ayn zamanda sörlesmenin muhtevasın belirleme özgürlüğäi ile ilı̣ilidir.

${ }^{1 t}$ Kiljan. 75.

12 Kilian, 76. 
engellemektir ${ }^{13}$. Sözleşme kuracak olan taraflardan birinin belirgin bir güce sahip olmasına bağlı olarak, bu tarafın kendi menfaatleri için yaptı̆̆ davranışlar hakkaniyete aykırı olabilir. O halde sözleşme kurma zorunluluğu piyasa ekonomisinin zararlı etkilerini önlemek ve ekonomi düzenini kontrol etmek açısından önem arzetmektedir.

Piyasa ekonomisinin amacı, herkes tarafından ihtiyaç duyulan veya istenen mal ve hizmetlerin mümkün olduğunca uygun şartlar altında teminini sağlamaktır. Mal veya hizmetleri talep eden kişi çok sayıda bağımsız işletmenin arzını değerlendirmekte ve kendisine en uygun olanını seçmektedir. Söz konusu işletmelerin kendi aralarında bir rekabetin bulunması, arzın uygun şartlar altında gerçekleşmesini sağlayacaktır. Bu şekilde talep sahipleri uygun şartları taşıyan mal ve hizmetleri alabileceklerdir. Bu sistemin yürümesi mal ve hizmet talebi olanun, bunları sağlayanlar arasında seçim yapabilmesine ve işletmelerin kendi aralarında rekabet yapmalarına bağlıdır. Piyasada belli bir mal veya hizmeti sağlayan işletme tekel durumunda ise veya rekabeti önleyecek kadar bir güce sahip ise bu sistem işlevini yerine getiremez. Insanların ihtiyacı olan mal ve hizmetlerin bir tek işletme tarafından saglanması halinde bu durum daha açık olarak ortaya çıkar. Bu tür işletmeler belli sözleşmeleri yapmaz, geciktirir veya mutad ya da uygun olmayan şartlar altında sözleşme kurmak isterse, kişilerin hayatlarını idame ettirmeleri veya ekonomik yaşamlarını sürdürmeleri engellenmiş olur. Böyle durumlarda sözleşme kurma zorunluluğunun bulunması gereklidir ${ }^{14}$.

Bu sinirlamalar sözleşme serbestisinin içinde tabii olarak bulunmaktadır ${ }^{15}$. Bunun dışında eşit durumda bulunan tüketiciler arasında ayırım yapılmaması, kişilerin yaşamsal ihtiyaçlarını temin edebilmeleri ve ekonomik özgürlügüun korunması gibi sebepler sözleşme özgürlügüne sınırlama getirilmesi düșüncesini ortaya çıkarmıştır ${ }^{16}$.

Sözleşme kurma zorunluluğu fonksiyonları bakımından iki ana başlık altında toplanabilir. İlk olarak rekabet sınırlamaları olan piyasalarda güç dengesi sağlanır. Bu daha çok mallarının satımında, hizmet piyasasında, ekonomik birlikler veya meslek birliklerinde görülür. Taraflar arasında güç bakımından eşitlik sağlandığı hallerde sözleşme kurma zorunluluğunun

\footnotetext{
${ }^{13}$ Merz, N.86; N.283; Kramcr, Art.19-20 N.1 14; Schönenberger/Jäggi, Art.l N.541; von Büren, 258: RGZ 133, 388 .

${ }^{14}$ Larenz, 43 ,

is Merz. N.86.

${ }^{16}$ Sözleşme ktırma zorunluluğunun diğer bir amacı sosyal adaleti sağlamaktır (Sclłluep. 194). Sözleşme özgürlüğü ile sözleşmede tarafłarnn denkliği arasındaki bağlantı için bkz. Ritgen, 116.
} 
tolere etme fonksiyonu ortaya çıkar. Ekonomik anlamda bireyleri güçsüzleştiren veya rekabet düzenini bozmak suretiyle işletmelerin yapısm zayıflatan piyasanın ilgililere açılmasi; ilgililer aleyhine bir durum doğacaksa sosyal güvencenin sağlanması; sosyal bir güç yaratıyorsa katılımın sağlanması ve bu birliklerin kontrol edilmesi fonksiyonlart öne çıkmaktadır ${ }^{17}$.

Sözleşme kurma zorunluluğuntn ikinci tür fonksiyonu, güçlü ekonomik veya politik etkilerin altında bulunan piyasalarda görülür. Bunlar enerji temini sözleşmeleri, ulaşım sözleşmeleri ve sübvánse edilmiş hizmet edimleri gibi alanlarda ortaya çımaktadır. Sözleşme kurma zorunluluğunun bu alanlardaki fonksiyonu aynı şartlarla hizmetten yararlanmanın sağlanmasıdır ${ }^{18}$.

\section{Benzer Hukuki Durumlardan Ayrılması}

Sözleşme kurma zorunluluğunun benzer hukuki durumlardan ayrılması böylece de sınırlanması gerekir. Taraflardan biri için irade beyanında bulunma külfetinin öngörüldduğï hallerde sözleşme kurma zorunluluğundan söz edilemez. İcaba karşı susmanın kabul olarak değerlendirildiği haller bu duruma örnek olarak verilebilir. Borçlar Kanununun 387'nci maddesinde vekilin derhal red beyanında bulunnaması halinde sözleşmeyi kabul etmiş olması bu tür bir haldir"

Borçlar Kanununun 7/III'üncü maddesinde düzenlenen "Semenini göstererek emtia teşhiri, kaideten icap addolunur" hükmü de sözleşme kurma zorunluluğunu düzenlememektedir. Çünküi semenini gösteren yazss ile vitrine bir mal konmuş olması, bu eylemi yapan tarafın isteği ile gerçekleşmiştir ${ }^{20}$.

III. Sözleşme Kurma Zorunlulığunun Kaynakları

\section{A. Genel Olarak}

Sözleşme kurma zorunluluğu kanundan veya sözleşmeden doğar. Sözleşmeden doğmasının en tipik örneği ön sözleşmedir ${ }^{21}$. Buna karş̧ılı ön

${ }^{17}$ Kilian. 74 .

${ }^{18}$ Kilistn. 74.

"Kramer, Art.19.20 N.97 ve bk\%. N.116.

"Kramer. Art.19-20 N.97: BGE II 26 (37).

"Ayruntılı bilgi için bkz. Herzog, 226 vd.; ayrıca bkz. Kramer. Art.22: Schöncuberger/Jägrgi, Art.1 N.542; Oftinger. 521 a; Gauch. Nr.453. Tarafar istedikleri zaman 
alım sözleşmesinde sözleşme kurma zorunluluğundan söz edilemez. Zira, söz konusu olan sadece sözleşmenin karşı tarafını seçme özgürlüğünün sinırlanmasidir ${ }^{22}$.

\section{B. Kanundan Doğan Sözleșme Kurma Zorunluluğu}

\section{Genel Olarak Kanundan Doğan Sözleşme Kurma Zorunluluğu}

Çok sayıda örneği bulunan kanundan doğan sözleşme kurma zorunluluğu kamu hukukuna veya özel hukuka ilişkin kanunlardan doğabilir. Bunların çoğu kamu hukukuna ilişkin kanunlardan doğmaktadır. Özel hukuka ilişkin kanunlara İsviçre Hukukunda yer alan ZGB Art.731'de düzenlenmiş bulunan şartların oluşması halinde komşu malik lehine irtifak hakkı tesis etme yükümlülüğ̈ü zikredilebiliı ${ }^{22 a}$.

Sözleşme kurma zorunluluğu kamu hukukuna ilişkin kanunlarla da getirilmiş olabilirr ${ }^{23}$.

Doğrudan doğruya kanundan doğan sözleşme kurma zorunluluğunda çeşitli ihtimaller bulunmaktadır. Kanunla bir kamu kuruluşu bir özel hukuk kişisi ile sözleşme kurmaya zorlanabilir. Kanun bir özel hukuk kişisi ile başka bir özel hukuk kişisi arasında sözleşme kurma zorunlulugu öngörebilir veya bu tür bir sözleşmenin muhtevası kanunla belirlenmiş olabilir.

Kanunla sözleşme kurma zorunluluğunun getirilmesi halinde talebin reddedilebilmesi sadece kanunda belirtilen şartların dışına çıkılması veya özel haklı bir red sebebinin bulunmasına bağlıdır.

Kanunla getirilen sözleşme kurma zorunluluğu sadece kamu hukukuna; kamu hukuku ile özel hukuka veya özel hukuka ilişkin olabilir. Bu nedenle bu tür bir sözleşme nedeniyle meydana getirilen ilişkinin kamu hukuku ilișkisi veya özel hukuk ilişkisi olması birbirinden ayrılmalıdır.

sözleşme görüşmelerini sona erdirebilir. Görïşmelere başlanması sözleşme kurma zorunluluğu doğurmaz.

${ }^{22}$ Kramer, Art.19-20, N.101.

2ะ Tüketicinin Korunması Hakkındaki Kanunun S'nci maddesine göre sözleşme kurma zorunluluğunua deǧerlendirilmesi jȩ̧in bkz. İnceoğlu Murat. Sözleşme Yapma Zorunluluğu ve Tüketicinin Korunması Hákkında Kanunun 5. Maddesinin bu açıdan değerlendirilmesi Prof. Dr. M. Kemal Oğuzman'ın anısına armağan. jstanbul, 2000.391 vd.

${ }^{73}$ Bkz. 4646 sayılı Doğal Gaz Piyasası Kanunu. 4628 sayılı Elektrik Piyasası Kanunu; Bu tür durumlarda hizmetin sağ Janmasına ilişkin açık bir kanuni hüküm bulunmalıdır (Nawiasky. 197). 
Sadece kamu hukukuna ilişkin olan sözleşme kurma zorunluluğunda bu zorunluluk bir kamu kuruluşu için öngörülmüş olabilir. Bu ihtimalde kamu kuruluşu özel hukuka ilişkin bir edimi, kanunla kendisine verilmiş bulunan bir görev nedeniyle sağlamakla yükümlï iken hak sahibi de ihtiyacını veya talebini münhasıran kamu hukukuna ait araçlarla giderebilmelidir ${ }^{2-}$. Kamu kuruluşunun talep edilen sözleşmeyi kurmaması halinde vesayet denetimi, "yetkili kurula" başvurma ve kurul karart ile talep edilen hizmetin hak sahibine siğllanması mümkün olur.

$\mathrm{Bu}$ tiir durumlarda kamu kuruluşları kendisine kanunta verilen bir görevi yerine getirmek amacıyla kişilerle sözleşme kurmaktadır. Kişiler bu hizmetlerden herhangi bir sinırlamaya tabi olmaksızın yararlanma talebinde bulunabilirler ${ }^{25}$. Bu durumda da hem özel hakuk kişisi hem de kamu kuruluşu iradelerini ortaya koymalıdır ${ }^{26}$.

Bir görüşe göre kamu kuruluşlarının kanunla kendine yüklenmiş bir ödevini yerine getirmek için kişilerle sözleşme kurması halinde sözleşmenin kurulmasıma ilişkin kurallar uygulanmaz ${ }^{27}$. Buna göre, bu tür durumlarda sözleşme kanunun uygulanmasının bir aracıdır ${ }^{28}$. Bu görüşe katılmıyoruz. Çünkü kanundan kaynaklanan ve bir kamu kuruluşunun bir özel hukuk kişisi ile sözleşme kurma zorunluluğunu öngören hallerde sözleşmenin karşı tarafını seçme özgürlüğü ve sözleşmenin muhtevasm belirleme özgürlü̆ğü kaldırılmaktadır. Ancak buna rağmen ortada bir sözleşme bulunmaktadır ${ }^{29}$. Ayrıca, Kanundan kaynaklanan sözleşme kurma zorunluluğunun özel hukukta hakim olan sözleşme anlayışına uygun dïşmemekte olduğu yaşam gerçeklerine uymayan doktriner bir daraltmadır ${ }^{30}$.

${ }^{24}$ Schönenlu'rger/Jäggi, Art.1 N.538; Devlete veya devlete ait bir kamu kuruluşuna ya da kendisine devlet tarafından imtiyaz tanınmış bir işletmeye sözleşmc kurnta zoruntulự̆u öngörülmüs olabilir (Ortinger, 509 a).

${ }^{25}$ Mer٪. N.27I; Kilian, 70: Nawiasky, 197. Bu durumda kanun önünde. dolayısıyla idare önünde csitlik ilkesi bułunmaktadır.

"Nawiasty. 197.

${ }^{27}$ Oltinger. 510 a, 512 a; Merz, N.27I. 178; Jdari Sözleşmeler için bk\%. Kutlu. II-39; Bu tür durumlarda yararlanıc kamu kuruluşlars ile sözleşıne kutmamakta, kúmt hukuku

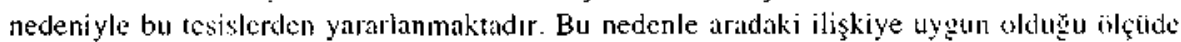

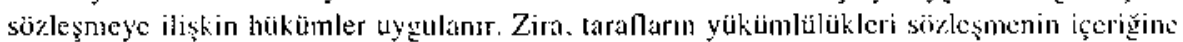
çok yakın bir durumdádır. O halde kámu kutumlarınıı özel hukuk ilişkisi yaratacak şekilde bazı hizmelleri temin etmesi ve sözleşme benzeri yükümlülükler yerine getimesi durumundiı BK md.97 ve md.l01 hüküm]cri uygulanır ( von Tuhr/Peter, 278, 281).

${ }^{2 x}$ Bilggi iẹin ble. Mer7. N.277.

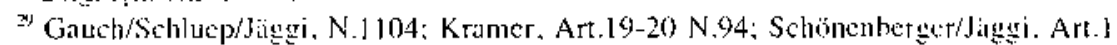
N.529. Yazara g̨öre sözleşme kurma zorunluluğundan doğan yükümlülük irade özgürlüğüune. ilişkin diğer hukuki sinırlamalar gibi istisnai bir durumdur.

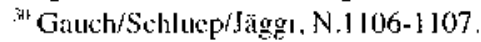


Hem kamu hukukuna hem de özel hukuka ilişkin sözleşme kurma zorunluluğunda sözleşme konusunun yerine getirilmesi bir yönüyle kamu hukukuna temas ederken diğer yönüyle özel hukuka temas etmektedir. Bu ihtimalde hizmet kamu hukukuna ait araçlarla sağlanır. Ancak talebin yerine getirilmemesi halinde hak sahibi hukuk mahkemelerinde ifa veya tazminat davası açabilir ${ }^{3 !}$.

Bu tür durumlarda kamu kuruluşları bir edim yerine getirmek zorundadır. Bu nedenle de kişiler yapılan işleme katılmak zorundadır. Buna Devlet Demiryollarının taşımacılık hizmetlerini, posta işletmesini ve telekomünikasyon hizmetlerini örnek olarak verebiliriz. Devlet Demiryolları, Posta İşletmeleri ve Türk Telekomünikasyon hizmetleri 233 sayılı Kanun Hükmünde Kararnamenin ekler bölümünde kamu iktisadi kuruluşu olarak kabul edilmiştir. Kararnamenin dördüncü maddesine göre bu teşebbüsler özel hukuk hükümlerine tabidir. Ayrıca bu hizmetler kendilerinin piyasada tekel olmaları nedeniyle talep sahiplerine sağlanmak zorundadır. Bu nedenle söz konusu teşebbüsler sözleşme kurma talebini reddetmeleri halinde hukuk mahkemelerinde açılacak davalara muhatap olacaklardır.

Kamu kuruluşlarının kanunla kendisine yüklenmiş bir ödevi yerine getirmesi dışında kişilerin emredici bir hükïmle kamu kuruluşları veya diğer özel kişilerle sözleşme kurma zorunluluğu konmuş olabilir. Böyle durumlarda da sözleşme ilişkisi özel hukuk kurallarına değil kamu hukuku kurallarına tabidir ${ }^{32}$. Ancak bu ihtimalde kamu kuruluşunun sözleşme kurmaması halinde özel hukuka ilişkin davalar açılabilir.

Bu duruma 4646 sayılı Doğal Gaz Piyasası Kanunu, 4628 sayılı Elektrik Piyasası Kanunu ve 4054 sayılı Rekabetin Korunması hakkında Kanun örnek olarak verilebilir.

Gerçekten Doğal Gaz Piyasası Kanununun ${ }^{33} 4 / 4 / \mathrm{e} / 2$ 'nci maddesinde toptan gaz satışı yapan tüzel kişilerle serbest tüketiciler sözleşme kurmak isterlerse, bu kişiler tüketicilere gaz bałlantısı yapmak zorundadır ${ }^{34}$.

\footnotetext{
${ }^{11}$ Schönenberger/Jäggi, Art.1 N.239, 541.

${ }^{32}$ Merz, N.271.

${ }^{33}$ 18.04.2001 tarih ve 4646 sayll Kanun.

${ }^{3}$ Bkz. aynı Kanunun 4/4/g/2'nci maddesi ve Doğal Gaz Piyasası Dağıtım ve Müşteri Hizmetleri Yönetmeliğinin (03.ll.2002 tarih ve 24925 sayllı Resmi Gazetede yayıntanmışır) $36^{\circ}$ ncı maddesi. Bu maddede sözleşme kurma zorunluluğu için dağıtım şirketinin bulunması gereken durum ile talep sahibinin mevzuatta öngörüten işlemleri yapması gereklitiği bağlantılandırılmıştır. Doğal Gaz Piyasası Lisans Yönetmeliğjnin 2 I 'nci maddesi aynt düzenlemeyi yapmıştır. ; Kanunun $8 / \mathrm{b}$ maddesinde ise hangi hallerde bu tür bir
} 
Doğal Gáz Piyasası Dağıtım ve Müşteri Hizmetleri Yönetmeliği'nin 36 'ncı maddesine göre, dağıtım şirketi tarafından bağlantı talebi reddedilen talep sahibi ilgili Kuruma başvurmalıdır. Kurul olayı inceledikten sonra dağıtım şirketinin nasıl hareket etmesi gerektiğini bildirir. Aynı şekilde Doğal Gaz Piyasası Lisans Yönetmeliğinin ${ }^{35} 21$ 'nci maddesine göre lisans sahipleri sisteme bağlanmak isteyen kullanıclarm bu talebini reddederse. talep sahibi Kuruma başvurur. Kurulun vereceği karar taraflan bağ $\operatorname{lar}^{36 "}$.

Ancak, hak sahibi hem doğal gaz hem de elektrik piyasası ile ilgili olarak, sözleşme kurma zorunluluğunt yerine getirmeyen dağıtıcılara ve lisans sahiplerine karşı tazminat davassı açabilecektir.

Elektrik Piyasası Kanununun $2 / \mathrm{b}$ ve $2 / \mathrm{c}$ maddelerinde sözleşme kurma zorunluluğu öngörülmüş ${ }^{37}$ Doğal Gaz Piyasası için belirttiğimiz düzenlemelere paralel hiikümler getirilmiştir.

Hizmet piyasalarında da kanundan doğan sözleşme kurma zorunluluğundan söz edilebilir. Gerçekten 4046 sayllı Özelleştirme Kanununun ${ }^{3 \not}$ 21 nci maddesine göre sakat statüsünde çalışanların işten çıarılamayacağı düzenlenmiştir. 1475 sayılı Iş Kanununun 25/A ve B maddesine göre ise 50 den fazla işçi çalışııranlar bu işyerlerinde $\% 3$ oranında sakat işçi ve bu oranda hükümliu çalıştırmak zorundadır ${ }^{39}$.

Sözleşme kurma yükümlüsü bir kamu kuruluşu olsa bile karşılıklı olarak iradelerin beyan edilmesi gereklidir. Kamu kuruluşu özel hukuk düzenine tabi işlemleri bakımından borçlar hukuku sözleşmeleri yapmaktadır. Böyle durumlarda genellikle kamu işletmesine ait form

talebin reddedilcbileceği düzenlenmektedir. Kanunun 11 'nci maddesinde eşit durumda bulunan serbest tüketiciler arasında ayırım yapılamayacağ hukıü getirilmiştir.

${ }^{36} 07.09 .2002$ tarih ve 24869 sayıli Resmi Gazetede yayınlanmıştır.

3t Aym Yönetmeliğin 28/ll' 'üncü maddesinde dağ zorunluluğu ifode cdildikten sonra hangi şartlarm bulunması halinde talebi reddedebilecekleri,

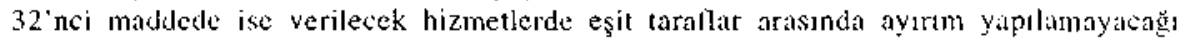
dïzenlennektedir.

"Kanunun ayms maddelerinde eşit laraflar arasında ayıtım yapslamalyacağ̣ höktme bağğanmış̧ır.

24.11.1994 tarihli Özelleştirme Uygutamalarının Düzenlenmesine ve Baz Kanun ve Kanun Hükmünde Kăramámede Değişiklih. Yaplmasına Dair Kamun.

"Bu yükümiülüğ̈ yerime getirmeyenler için aym Kananun 98 nci mâddestnde cezat hükümleri getirılmiştir. Sakat işçi çalıştırılımasına ilişkin esasları belirlemek maksadıyla bir tüzük çlk arıltııştır (Resmi Gazete 16.03.1987 tarih ve 19402 sayı). 
doldurulur ve işletmeye verilir. Bu formun kişilere verilmesi sözleşmenin kurulmasına ilişkin rıza anlamına gelmektedir ${ }^{40}$.

Sadece özel hukuka ilişkin sözleşme kurma zorunluluğunda hizmet kamu kuruluşu tarafından sağlansa dahi, görev dolayısıyla temin edilmemektedir. Bu durumda kanun bir özel hukuk ilişkisinin muhtevasını düzenlemektedir. Böyle durumlarda sözleşme kurma zorunluluğu ilk bakışta dikkati çekmez. Çünkü bu tür ilişkilerde ön planda görülen husus sözleşme değil, ihtiyaç duyulan bir şeyin teminidir. Malikin belli şartlarm bulunması halinde komşu lehine irtifak hakkı tesis etmesi, miras taksimine katılma veya sürekli bir borç iliş̧isinin sona ermesinde sözleşme hükümlerine göre tasfiyeye katılma halleri bu duruma örnek olarak verilebilir ${ }^{41}$.

\section{Rekabet Hukukundan Doğan Sözleşme Kurma Zorunluluğu}

Rekabetin Korunması hakkmdaki Kanunun 4'üncï maddesine göre "Belirli bir mal ve hizmet piyasasında doğrudan veya dolaylı olarak rekabeti engelleme, bozma ya da kısitlama amacını taşıyan veya bu etkiyi đoğuran yahut doğurabilecek nitelikte olan teşebbüsler arası anlaşmalar, uyumlu eylemler ve teşebbüs birliklerinin bu tür karar ve eylemleri hukuka aykırı ve yasaktır". Aynı Kanunun 6'ncı maddesine göre hakim durumda bulunan bir veya birden fazla teşebbüsün bu hakim durumunu kötüye kullanması yasaklanmıştır. Düzenlemeye göre örneğin hakim durumda bulunan bir teşebbüs eşit durumdaki alıcılara eşit yükümlülükler ve sözleşme şartları koyabilir ${ }^{42}$. Bu şekilde davranmayan işletme ayırımcılık yapma yasağını ihlal etmiş olur.

Hakim durumda bulunan işletme rekabeti hissedilir şekilde ihlal etmişse sözleşme kurma zorunluluğu doğar ${ }^{43}$. Hakim durumda bulunan işletme bu durumunu bir rekabet politikası aracı olarak kullanyorsa; böylece fiyatlanı istediği gibi belirleme veya sözleşme şartlarının kendi lehine düzenleme amacıyla ${ }^{44}$ sözleşme kurma taleplerini reddediyorsa sözleşme kurma zorunluluğu söz konusu olabilir. Zira burada edimlerin rekabet konusu

Nawiasky, 198.

${ }^{+i}$ Schönenberger/Jäggi, Art.1 N 540 .

${ }^{12}$ Bu dutrum Anayasada yer alan eşitlik ilkesirin özel bir ifadesidir (Kilian, 60); Hakim durumun kötüye kullanılmasının bir yansıması olan áyırnmcılık yapılması ile ilgifi olarak bkz. Badur, 150 vđ., Öz, 152-153/III Bölüm 4.3.2.3.2. Avrupa Birliği'nde Hakim Durumun Kötüye Kullanılması, Ankara 1998 (Tüsiad yayını), 68, Esin, 189 vd., Aslan, 104 vd.

${ }^{43}$ Kilian, 63; Rekabet hukukunda yer alan bu tür düzenlemeler Anayasada düzenlenen sosyal devlet anlayışının sonucudur (Dilcher, 1042)

${ }^{44}$ bkz. 4054 sayılı Kanun m.3. 
olmasına aykırılık ve piyasanın ilgililere açık bulunması ilkesi ihla] edilmektedir ${ }^{-15}$.

Böyle durumlarda Kanunun dokuzuncu maddesine göre Kurul, ilģili işletmeye yerine getirmesi veya kaçınması gereken davranışı bildirebilir. Bu, Kurulun ilgili işletmeye sözleşme kurması talimatı anlamına gelir ${ }^{\text {tin }}$.

Rekabet hukukundan kaynaklanan sözleşme kurma zorunluluğunda, hakim durumun kötüye kullanılması söz konusudur. Hakim durumunu kötüye kullanan işletme, karşısında bulunan zayıf durumdaki kişinin sözleşme özgürlíğünüi sınırlamaktadır. Haksız engellemelerin veya talep sahipleri arasında farklı uygulamaların bulunduğu durumlarda sözleşme kurma talebinin veya sözleşmenin mutad ya da uygun şartlarda kurulması talebinin reddi sözleşme kurma zorunluluğunu doğurưr ${ }^{47}$.

Rekabet Hukukundan doğan sözleşme kurma zorunluluğundan tüketiciler yararlanamaz. Çünküi 4054 sayılı Kanunun 4-7'nci maddelerinde yer alan düzenlemeler ticari piyasanın işlemesine ilişkindir. O halde bu hükuimlerden üreticiler ve tacirler yararlanabilmektedir ${ }^{40}$.

Makul sebepler bulunmadığ 1 sürece piyasada hakim durumda bulunan işletme talep sahibi ile sözleşme kurmak zorundadır. Bu tür bir talebin reddi hakim durumun kötuiye kullanılmasına yol açmaktadır ${ }^{49}$.

Hakim durumda bulunan bir işletme iki sebeple sözleşme kurma yükümlüsü olabilir. Hakim durumda bulunan işletmenin sürekli alıcısının sözleşne kurma talebi makul bir sebep olmaksizm reddedilemez. Bunun dışında bir işletmenin ticari varlığını sürdürmesi için temin etmesi gereken temel kaynağın hakim durumda bulunan işletme tarafından makul bir sebep olmaksızın sózleşme konusu yapılmamasıdır. Bu ihtimalde kaynak ihtiyacı olan işletme söz konusu işletme ihtiyacını başka bir firmadan da temin edememelidir. Alternatif temin imkanının bulunduğu hallerde sözleşme kurma zorunluluğu söz konusu olmaz ${ }^{501}$.

t5 Kilian, 63: Büylece rekabet ozgurlüğünü tehlikeye sokan sözleşme örgìtriugü sınırlanınaktadır. Aynı zamanda rekabet özgüurlüğü özel hukukun değerler sistem içine girmiş̧ir (Dilcher. 1042, 1043).

thinwenzet, 139.

${ }^{17}$ Laren $\% .44$.

${ }^{4 x}$ bkz.Kilian. 82: Sanl1. 16; 4054 sayılı Kanunun 2"nci maddesi de bu anlankliadır.

4) Avrupa Birliği'nde Hakim Durumun Kötüye Kullanılması. Ankara 1998 (Tüsiad yayını), 60 .

${ }^{5}$ Rekabet Kurulunun 21.12.2000 tarih ve 00-50/533-295 sayil kararı. 


\section{Genel Sözleşme Kurma Zorunluluğu}

\section{Genel Olarak}

Kanuna dayanan sözleşme kurma zorunluluğunun hukuki temellerinin incelenmesinde münferit özel hukuk düzenlemeleri ile kamu hukuku düzenlemeleri arasındaki durum ve bazen anayasa hukukuna ilişkin temel haklarla ilgili olup özel hukuka ilişkin hukuk ilkelerinden hareketle genel bir sözleşme kurma zorunluluğunun türetilip türetilemeyeceği incelenmelidir" ${ }^{\text {si }}$.

Özel hukukta ekonomik bakımdan zayıf olan tarafı koruyucu hükümlere esas itibariyle ihtiyaç bulunmamaktadır. Ancak, sözleşme ekonomik açıdan güçlü olanın diğer taraf üzerinde hakimiyet kullanma aracı olarak da kullanılamaz. Bu nedenle çok aşırı durumlar için sözleşme kurma zorunluluğu zayıf tarafı korumak düşüncesiyle öngörülebilir ${ }^{5 ?}$.

Kamu hukukundan kaynaklanan ya da kamu hukukuna benzerlik arz eden sözleşme kurma zorunluluğu veya sözleşme kurma talebini kabul zorunluluğu dışında kalan sözleşme kurma zorunluluğu halleri bulunmaktadır ${ }^{53}$. Bu ihtimalde hak sahibi ile yükümlü özel hukuk kişileridir. $\mathrm{Bu}$ durumda taraflar arasında somut bir hukuki ilişki bulunmalıdır. Bu ilişki en azından hak sahibi lehine tazminat talebine imkan veren şahsi bir talebi doğurmuş olmalıdıšs. Yukarıda anılan düzenlemeler dışında kişilik hakkından ve ahlaka aykırı zarar verme yasağından kaynaklanan bir sözleşme kurma zorunlulugundan söz edebiliriz.

Genel sözleşme kurma zorunluluğu hallerinde özel hukuk alanında meydana gelen bir ivaz karşılığı malların ve hizmet edimlerinin hukuki işleme konu edilmesi söz konusudur ${ }^{55}$.

Kanuni bir düzenleme bulunmadiğı halde özel hukukun genel prensiplerinden veya temel haklara ilişkin mülahazalardan hareketle sözleşme kurma zorunluluğu öngörülebilir. Bu konuda sözleşme özgürlüğünün fonksiyon şartlarından hareketle ilke olarak genel bir sözleşme kurma zorunluluğundan söz edilebilir. Taraflar arasında şekli bir eşitlik

\footnotetext{
${ }^{51}$ Kramer, Art.19-20 N.97.

${ }^{52}$ Schmidt-Salzer. (Vertragsfreiheit), 11; BGE 80 II 26 (37),

${ }^{53}$ Bydlinski, 6; Kramer. Art.19-20 N.108-109.

${ }^{54}$ Bydlinski, 6 .

55 Örneğin kitle iletişim araçlarının özellikle yazılı basının ilan veya reklam talepleri bulunmast halinde sözleşme kurma zorunluluğa: kablolu yayın elektronik posta gibi hizmetlerin sağlayan işletmelerin sözleşme kurma zorunluluğu. Ayrıntılı bilgi için bkz.
} Kilian, 71 vd. 
olduğu kabul edilirse, taraflardan biri fiilen diğer tarafa uygun olmayan şartları kabul ettirebilecek kadar güçlü durumda bulunuyorsa ve bu sözleşme prensibine taban tabana zit ise bu durumdaki taraf sözleşmeyi kurmàmak suretiyle eşit olmayan durumundan ahlaka aykırı surette yararlanyorsa sözleşme kurma zorunluluğu kabul edilmelidir ${ }^{56}$.

\section{Sözleşme Kurma Zorunluluğunun Unsurları}

\section{aa. Sözleşmeyi kurmak isteyen tarafın hak sahibi olması}

Sözleşme kurma yüküimlülüği doğuracak şekilde sözleşme kurmaya ilişkin irade beyanında bulunan kişinin öncelikle zaruri bir ihtiyaç içinde bulunması gereklidir. Bu ihtiyaç giderilmediği takdirde, kişinin kişisel bütünlüğüüün veya malvarlığının tehlikeye düşmesi söz konusudur. Kişilerin ihtiyaç duyduğu yaşamsal maddelerin temini zorunluluğu, bu kişileri hak sahibi yapar. Ekonomik yaşamı sürdürebilme unsuru da bu kapsamda değerlendirilir ${ }^{57}$. Örneğin bir şirketin ticari varlığını devam ettirmesi için bir hammadde almast gerekli ise sözleşme kurma zorunluluğundan söz edilebilir. Ancak, ırk ayırımı nedeniyle sözleşmenin kurulmaması halinde sözleşme konusunun yaşamsal bir ihtiyacı giderip gidermediği unsuru aranmaz ${ }^{58}$.

Sözleşme kurma zorunluluğunu doğuran diğer bir durum söz konusu ihtiyacın eşit şartlar altında sunulmamasıdır ${ }^{59}$. Bu şekilde sözleşme kurmak isteyenler arasımda ayırımcılı yapan işletme bakımından sözleşme kurma zorunluluğunun kapsamı genişlemektedir. Ayırımcılığın söz konusı olduğu hallerde sözleşme kurmak isteyenin hak sahibi olması yaşamsal ihtiyaç için gerekli olan edimler dışında kalan daha az önemli mallar ve hizmetler için de

So Kramer, Art.19-20 N.108-109; Taraflardan birinin ekonomik bakımdan diğerine gore çok güçlü olduğ durumlarda tek taraflı belirienen şartlara uyulmak zorunda kalınıyorsa "sözleşme mekanizması" fonksiyonlasın yerine getiremez. Bu durumda zalyı1 taralin irade beyan sö $/$ leşmenin hükümlcrini değerlendiren ve serbest olarak menfaatlerine tartan bir gởrünüm ar\% edeceğ̣i yerde ekonomik açıdan güçlü olan tarafın tek tarallı olarak belirlediựi ફ̧artların onaylanması anlamına gelmektedir (Schmidt-Zalzer, 173, 175).

${ }^{57}$ Kişilerin zaruti ihtiyaçları -yaşansal önem- bakımından bkz.Kilian. 52. 60-60: Kramer. Art. I9-20 N.110. 115: Schönenberger/Jäggi, Vorb. Vor Art.I N.1 I5. Art.1 N.54I:

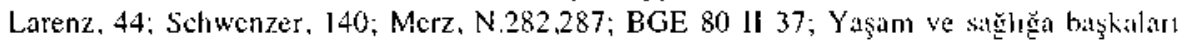
tarafindan yapian her mijdahale hukuka aykırıdır. Bu nedenle Devletin bu duruma izin vermesi bekieneme (Ritgen. 118-119); Kişiliğin korunması bakımından bk\%. Met\%. N.8. 97.

\footnotetext{
2* Palandt/Heinrichs, Einf.v\$ 145 Rdnr.8.

${ }^{\text {sty }}$ Lasenz, 44.
} 
söz konusu olur ${ }^{\text {0 }}$. Hakim durumda bulunan taraf kişinin sözleşme talebini kabul etmekle birlikte ağır sözleşme şartları ileri sürüyorsa, bu durumda uygun şartları içeren sözleşmeyi kurmakla yükümlü sayılmalıdır.

Sözleşme kurma yükümlülügüu doğuracak şekilde irade beyanında bulunmaya hak sahibi olmayan kişi, irade beyanıyla sözleşme kurma yükümlülügü doğuramaz.

Kişinin hak sahibi olmasında iki önemli düşünce rol oynamaktadır. Bunlardan birincisi kişiliğin korunması, ikincisi ise ekonomi yaşamının gerekleridir ${ }^{61}$. Ekonomi yaşamının gerekleri de son tahlilde kişilerin korunması, huzur ve refahının sağlanmasına ilişkindir. Zira konumuz bakımından piyasa ekonomisi kişiliğin gelişmesi düşüncesine ve rekabetin yararlı fonksiyonlarına dayanmaktadır ${ }^{62}$.

Sözleşme özgürlüğginün bir parçası olan rekabet özgürlüğü de kişilerin malvarlıklarını korumaktadır. Rekabet özgürlügünün kaldırılmasına yol açacak şekilde boykota gidilmesi, işletmelerin topluca belli bir malı satmamaları veya belli gruplar arasında ayırımcılık yapılması belli düzenlemelerle sinırlandırılmış ve toplumda yaşayan kişilerin ekonomik özgürlükleri sağlanmaya çalışlmışıtı ${ }^{63}$.

\section{bb. Kendisiyle sözleşme kurulmak istenen tarafin hakim durumda olması}

Sözleşme kurma yükümlülüğgu altında bulunan kişiler piyasada hakim durumda bulunmalıdır. Böyle bir durumda bulunan kişinin hak sahibi ile sözleşme kurmak istememesi veya normalin üstünde ağır şartlarla sözleşme kurmak istemesi hakkın kötüye kullanılması oluşturmaktadır.

Piyasada hakim durumda bulunma kişinin öncelikle yasal veya frili tekel olmasına bağlıdır ${ }^{64}$. Sözleşme kurma zorunluluğunda yasal tekel veya

"xilian, 61.

${ }^{61}$ Merz, N.88.

${ }^{\text {oz }}$ Merz, N.90; Sözleşme serbestisinin fiili sınırları anlamında genel işlem şartlarına ilişkin değerlendirme için bkz.Merz, N.92-96.

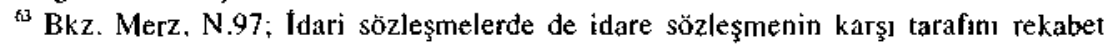
kurallarını gözeterek tarafsız ve aleni bir şekilde seçmek zorundadır (Kutlu, 48).

at Schluep, 193 vd.; Schönenberger/Jäggi. Art.1 N.541; von Tuhr/Peter, 284; Schwenzer, 298; Merz. N.283; Kiljan, 56; Ritgen, 119; Palandt/Heinrichs, Einf.v\$ 145 Rdnr.8; BGE 86 II 373; Sözleşme mekanizması sözleşmenin muhtevası bakımından tarafların eşit olmasını sağlamaktadır. Ancak tekel sözleşmelerinde rekabeti sınırlayan anlaşmalar tüketicilerin aleyhinc durumlar yaratı̆̆ından sözleşmenin taraflatı dışınđa etkiler 
tekel benzeri organizasyonların varlığı aranır ${ }^{65}$. Ancak ayırım yapma yasağ bakımındån yükümlünün hakim durumda bulumması şartı aranmaz. Bunun yerine piyasada güçlü durumda bulunması yeterlidior ${ }^{\text {thit }}$.

Piyasada hakim durumda olma sözleşme kurma zorunluluğunun tanınması için tek kriter olmamakla birlikte en önemli niteliktir ${ }^{\text {th }}$. Burada önemli olan kişilerin ihtiyacını başka bir kişi veya işletmeden sağlayamayacak olmasıdır. Bunun dışında fiili bir tekelin kamu yaran veya piyasanın işleyişi bakınından vazgeçilmez olması şartı aranmaktadır ${ }^{\text {tï. }}$.

Ayn alanda birden fazla tekel durumunda işletme bulunuyor ve bunlardan hiçbiri sözleşme kurma talebini kabul etmiyorsa, hangi işletmenin sözleşme kurma yükümlüsü olduğu konusu incelenmelidir.

\section{cc. Hak Sahibinin Talebi}

Sözleşme kurma zorunluluğunun söz konusu olması hak sahibinin yükümliuye sözleşme kurma talebini iletmesine bağlıdır. Hak sahibinin sözleşme kurma zorunluluğununnun söz konusu olduğu hallerde böyle bir sözleşme kurma teklifini iletmemesi yủkümlülüğgün de söz konusu olmamasına yol açar. Bu anlamda hak sahibinin talepte bulunması, sözleşme kurma zorunluluğunun yükïmlülüğe dönüşmesine sebep olmaktadır.

Bu tür bir sözleşme kurma talebi ile karşılaşan hakim durumdaki kişi için sözleşmenin kurulmasına ilişkin bir irade beyanında bulunma yükümlülụ̧̈ưi doğar ${ }^{6 y}$.

doğurmaktadar (Schmidt-Salzer, 175 ve Schmidt-Salzer, (Grundfragen), 8. 9); Rekabet Hukuku bakıtıındal hakim durum kavramı için bkz. 4054 sayılı Kanun mu.3: Rekahe Kutulunun 21.12.2000 tarih ve 00-50/533-295 sayıl kararı. Badur. 96 vd.. Oे $/ .116$ vol/lll.Bölü̆n 3.2 ve 561 va./IV.Bölüm 2.2; Avrupa Birliğjinde Hakim Durumtın Kötujye Kullanılması, Ankara 1998 (Tüsiad yayın). 41 vd.; Esin 180 vd.; Aslan. 212 vd.: Aslan. Sempozyum. 55 vd

ths Schluep, 193 vi.: SchönenbergerfJäggi, Art.I N.541.

Kin Kilian. 61

6) Killan. 56; bkz. Larenz.. 44; von Tuhr/Peter. 284.

this Kilian, 58

th Sö̀leşmenin kurulması safhası ve tarafların belirlemediği yau noktaların belirlenmesi konusunda bkz. Bydlinski. Kontrahierungszwang. 379 vd. 


\section{dd. Sözleşme Kurma Talebinin Kabul Edilmemesinin Hukuka Aykırı Olması}

Sözleşme kurma talebinin kabul edilmemesi veya uygun şartlar ileri sürülmemesi hukuka aykırı olmalıdır. Aksi takdirde sözleşmenin kurulması zorunluluğundan söz edilemez. Zira, her sözleşme kurma talebinin reddi sözleşme kurma zorunluluğu doğurmaz. Çünkü her sözleşme kurma talebinin reddi hukuka aykırı değildir. Hakim durumda bulunan işletmenin hukuka aykırı davranması çeşitli şekillerde ortaya çıkabilir.

İlk olarak hakim durumda bulunan kişinin bu tür bir davranışı sözleşme kurmak isteyen tarafın kişilik hakkını ihlal edebilir ${ }^{70}$. Yukarıda izah edildiği gibi zaruri bir ihtiyacı bulunan ve bu nedenle de sözleşme kurmada hak sahibi olan kişinin bu talebinin yerine getirilmemesi hukuka aykırı bir durum arz eder. Zaruret halinde doktorlarin ve eczacilarin talebi kabul etmemeleri halinde kişilik hakkıntn ihlali söz konusu olmaktadır ${ }^{7 !}$.

Piyasanın geneline sunulan bir mal veya hizmetin arzı veya talebi nedeniyle kimse belirli bir kişi ile sözleşme kurmak zorunda değildir. Ancak, sözleşmenin karşı tarafını seçme özgürlüŭgü talep sahiplerinin belli özellikleri nedeniyle kötïye kullanılıyorsa kişilik hakkının ihlalinden söz edilebilir. Sözleşme kurmak isteyen kişinin sadece cinsiyeti, ırkı, yaşı, sağlık durumu, dini, mezhebi, politik görüşleri veya anayasal haklarını kullanması nedeniyle sözleşme kurulmuyorsa bu tür bir durum bulunmaktadyr ${ }^{72}$.

Kanunun bir kişi ile sözleşme kurmayı yasakladığı hallerde kişilik hakkının ihlali söz konusu olmaz ${ }^{73}$. Aynı şekilde sözleşme kurmak isteyen

Merz. N.277, 283; Schwenzer, 139, 298: Gauch/Schluep/Jäggi, N.1112; Kramer, Art.19-20 N.111-1 12; Zäch, 25; Jäggi, 354-355; Canaris, 243; Schönenberger/Jäggi, Art.l N.541; von Büren, 258.

"Schönenberger/Jäggi, Art.1 N.541; Kramer, Art.19.20 N.115; von Büren. 258; İsviçre Federal Mahkemesi kişılik hakkının ihlalinin söz konusu olması için kişilik hakkının sadece yetkisiz tecavüzlere konu olması gerektiğini ifade etmişti (BGE 80 II 26 (38).

${ }^{22}$ Gauch/Schluep/Jäggi, N.1l!l; Canatis, 243; Zäch. 26. Özellikle daha önce çalışan erkek iş̧̧ilere ödenen ücreti kadılara vermekten kaçınmak için belli işlere kadın işçilerin alınmaması: Bu konuda bkz. Birleşmiş Milletler Kadınlara Karşı her türlü Ayrımcılığın Önlenmesi Sözleşmesi (03.09.1981 tarihinde yürürrlüğe gìren bu sözleşme Türkiye tarafından 24.07.1985 tarihinde onaylanmıştır -Resmi Gazete 14.10.1985 tarih ve 18898 sayı-. Anayasal haklar ile özel hukukun kesişme noktaları için bkz Schwabe, 2 vd.; Sosyal devlete ilişkin anayasal ilkeler ile sözleşme serbestisi bağlantısı için bkz. Dilcher. 1043 ve Palandt/Heinrichs, Einf. $v \$ 145 \mathrm{Rdnt} .7$; Anayasa hukuku nomlan kişilerie devlet arasındaki ilişskileri değil, kişiler arasındaki hukuk ilişkilerini de düzenlemektedir (Bucher, 37).

${ }^{73}$ Yabancı kjşilerin birinci derece askeri bölgelerde taşınnaz edinemeyeceğine ilişkin düzenlemeler. 
kişinin kişisel nitelikleri ve hakkını kullanması kurulmak istenen sözleşmenin muhtevası ile uyumlu değil ise, diğer bir ifade ile bu sözleşmenin ilgili ile kurulması halinde diğer tarafa ağır bir yük getiriyorsa, kısacası sözleşmeden beklenen yarar bu kişiden beklenemeyecek ise yine kişilik hakkının ihlalinden söz edilemez ${ }^{74}$. Buna karşılık, örneğin ilgilinin sözleşme kurma talebi sadece cinsiyetinden dolayı, cinsiyet sözleşme için vazgeçilmez bir unsur olmadığı halde, reddedilirse kişilik hakkı ihlal edilmiş olur. Aynı şekilde yabancı olduğu için bir hasta hastaneye, özel bir okula veya restauranta kabul edilmiyorsa kişilik hakkı ihlal edilmiş olur ${ }^{75}$.

Piyasada fïlit tekel konumunda bulunan bir kişi topluma yönelik bir icapta bulunmuşsa, bu icaba karşlık veren herkese eşit davranmakla yükümlüdür. Eşit davranma yükümlülügün ihlali doğruluk ve dürüstlük kurallarına ayk irılık oluşturur ${ }^{76}$.

Rekabet hukukunun gelişmesi ile kişilik hakkının ihlaline dayanan sözleşme kurma zorunluluğu önemini yitirmeye başlamıştır. Ancak rekabet hukukunun düzenleme konusu yapmadığı alanlarda kişilik hakkının ihlali unsuru önem arz etmektedir ${ }^{7}$. Örneğin sosyal amaçlar güden bir derneğin üyelik talebini reddetmesi halinde, kartel veya kartel benzeri bir yapılanma söz konusu olmadığı halde sözleşme kurma zorunluluğu bulunabilmektedir. Sendikalara, barolara ve benzer diğer kuruluşların üyelik talebini reddetmesi halinde aynı durum söz konusudur ${ }^{78}$.

Bunun dışında sözleşme kurma talebini kabul etmeyen taraf ahlaka aykırı surette davranmış olmalı bu şekilde talep sahibine zarar vermiş olmalıdır ${ }^{79}$. Ahlaka aykırı bir hareketle başkalarına zarar vermek (BK' md.4//II) Anayasada yer alan eşitlik ilkesinin özel hukukta ifade ediliş şeklini oluşıurmaktadır. Eşitlik ilkesine aykırı ayırımcılık yapma yasağı

${ }^{7+}$ Gauch/Schluep/Jäggi, N.I112.

${ }^{75}$ Gauch/Schlıep/Jäggi, N.1112; Bucher'e göre (42) kişilik hakkının ilalaline ilişkin hükümlere dayanmak bu tür durumlarda amaca uygun sonuç doğurmaz. Zira. kişilik hakkı herkese katşı ileri sürülebilen. hak sahibine bir olumlu bir davranışın talep edilmesi yetkisi vermeyen sadece muidahalenin meni talebini doğuran bir haktır. Aytıca Seclig kararinda (BGE 80 Il 26) olduğu gibi kişilik hakkının ihlaline dayanılması sadece ilg̣iliyi korur. Ancak basın ozgüirlüğüüï korumaz.

The Kilian. 56. Ayrıca bkz. aşağıda dn.79 metni.

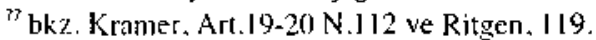

${ }^{7 *}$ Kramer. Art.19-20 N.112 ayrica bkz.N.115.

"von Tulw/Peter, 284; Merz, N.277; Kramer, Att.19-20 N.108-109; Schwenzer. 139, 298: Bydlinski, 10; Kramer. Art.19-20 N.111: Merz, N.271; Bydlinski, Kontrahicrungszwang. 385; Eren. C.l. 584: Oguzman/Öz, 513; Canaris, 243; Palandt/Heinrichs, Einl. $v \$ 145$ Rdnr.8: BGE 80 II 37; RGZ 48, 117; RGZ 133 388; Sözleşme özgürlügüünün ahlaka aykırı olarak kötüye kullanılması kavramı için bkz. Diłcher, 1043. 
sözleşme kurma zorunluluğuna yol açmaktadır. Bir tiyatro eleştirmeninin oyuna ilişkin yazacağı yazıdan dolayı tiyatroya almmaması bu duruma örnek olarak verilebilir ${ }^{30}$. Fiili bir tekel halkın ortak yararı veya piyasanın işleyiş şartları bakımından vazgeçilmez nitelikte ise, bu işletme sahibi de sözleşme kurmak isteyen kişilere aynı şekilde davranmak zorundadır. Burada da kişilere farklı davranıIması ahlaka aykırılık oluşturmaktadı ${ }^{81}$. Fiili tekel sözleşme kurmak isteyenlerle genel şartlar dairesinde sözleşme kurmak zorundadir.

Yukarıda ifade edildiği gibi ahlaka aykırı bir fiil ile kasden başkasına zarar verme hali eşitlik ilkesinin ihlal edildiği hallerde de meydana gelmektedir ${ }^{82}$.

Ancak Borçlar Kanununun 41/II’nci maddesinde düzenlenen bu kuralın uygulama alanı kişilik hakkının genişlemesi ile hakkın kötüye kullanılması yasağının hukuka aykırılık sayılması ile daralmıştır ${ }^{83}$.

Hakkın kötüye kullanılması ile hukuka aykırılık dışında sözleşme kurma zorunluluğu dürüstlïk kuralına da dayanabilir (MK m.2). Dürüstliuk kuralı sözleşme kurma yükümlülügüü öngördüğü hallerde, sözleşmenin kurulmaması dürüstlük kuralına aykırılık oluşturur. ${ }^{3 / 4}$

\section{Sözleşme Kurma Zorunluluğunun İhlalinin Hüküm ve Sonuçları}

Münhasıran kamu hukukuna ait olan sözleşme kurma zorunluluğu hallerinde, sözleşme kurma zorunluluğunu yerine getirmeyen idare aleyhine

\footnotetext{
${ }^{80}$ Alman Yüksek Mahkemesinin verdiğ bir kararda (RGZ 133,388 vd. Benzer bir karar için bkz.BGE 80 Il 26 ve kararın eleştirisi için Jäggi, SJZ 23353 vd.) tiyatro eleştirmeni Faust'un sahneye konulmasını izlemek istemiş, ancak salona alınmamışt. Eleştirmen gizlice salona girmiş, tanınması üzerine dışarı çıkanimış̧ı. Eleştirmen tazminat davası açmış mahkeme bu talebi redỏetmişti. Talebin reddi sebepleri günümüzde kabul edilmemektedir. İşletıme talep sahiplerine eşit davranmalıdır. Bunun dışında ifade özgürlüğù ve meslek icra etme özgürlüğü de korunmalıdır (Kilian, 70; Larenz, 47-48; Bucher (42) bu tür durumlarda sadece özel hukuka ilişkin normlara dayanımaması, aksine anayașa hukuku normlarının değerjendirilmesi gerektiğini ifade etmektedir); Anayasal haklar jle kişilik hakkı bağlantısı için bkz.Kramer. Art.19-20 N.112 ve Ritgen, 119.

${ }^{81}$ bkz. RGZ 48, 117 .

${ }^{\$ 2}$ Merz, N.277; Kilian, 52, 73. Alman Hukukunda eşitlik ilkesine dayalı sözleşme kurma zorunlulư̆u sadece yaşamsal mal ve hizmetler bakımından kabul edilmektedir. Ancak kapsam bu kadar dar olmamalidır (Kilian, 60).

${ }^{83}$ Eren. C.I. 583; Oğuzman/Öz, 512 .

\$4 Kramer, Art.19-20 N.111; Merz, N.283; Kilian, 57; SchönenbergerfJäggi. Art.1 N.54 1; von Büren, 258; Oğuzman/Öz, 133; BGE 86 Il 373; İmparatorluk Mahkemesi kötüye kullanmayı kabul etmemiştı (RGZ 133 388); ekonomik gücün kötüye kullanılması ve haksız avantajların sağlanması için bkz. Schmidt-Salzer, 175.
} 
idare hukuku ilkelerine göre iptal davası veya tam yargı davası açılabilir. Bunun dışında yetkili bir kurulun bulunması halinde bu konuda yapılan şikayetler üzerine kurul idareye nasıl davranması gerektiğini, bu anlamda hizmetin saglanması talimatmı verebilir.

Rekabet Hukukuna göre hakim durumunu kötüye kullanan 4054 sayılı kanuna göre Rekabet Kurulunun kararıyla idari para cezası niteliğinde bulunan (m.18) para cezasına veya süreli para cezasına mahkum edilir (n.16/II ve m.17). Aynı Kanunun 57'nci maddesine göre hakim durumu kötüye kullanan zarar görenin her tïrlü zararımı karşılamakla yükümlüdür ${ }^{35}$. Rekabet Kurulu Kanunun 9'uncu maddesine göre hakim durumunu kötüye kullananlara yapması gereken davranışı veya kaçınması gereken davranı̧̧ı bildirebilir. Bu anlamda hakim durumda bulunan ve sözleşme kurma talebini reddeden kişiye sözleşmeyi kurması gerektiğini bildirebilir.

Genel sözleşme kurma zorunluluğu hallerinde yükümlü sözleşme kurma talebini kabul etmek zorundadır. Bu talebi kabul etmeyen yükümlü aleyhine ifa davası açılabilir ${ }^{x 6}$. Ancak yükümlïnün irade beyanı yerine mahkeme hükmü esas itibariyle talep edilemez ${ }^{87}$. Ancak, yükümlünün kurmak istemediği sözleşmede edim tam olarak belli değil ise mahkeme hükmü ile irade beyanı săğlanabilir ${ }^{88}$. Sözleşme kurma zorunluluğunun doğması için yükümlünün kusuru gerekli değildiri ${ }^{8 y}$.

Mahkeme hükmü ile sözleşmenin kurulması halinde tabii ikameden (natural restitution) söz edilir ${ }^{\$ *}$. Bu durunda sözleşme kurma

"s Ayrica bkz.m.58 ve 59.

th Kramer. Art.19-29: Schönenberger/Jäggi, Art.1 N.538; Bydlinski, Kontrahierungszwang, 384: Kiliăn, 82; Buna karşılık müdahalenin meni talebi kabul edilemez. Yükümlünün müdahalenin meni dolayısıyla bir davranışa zorlanması anlamsızdır. "Malları teslim etmemenin menine" karar verilemez. Bu müdahalenin meninin hukuki durumu ile

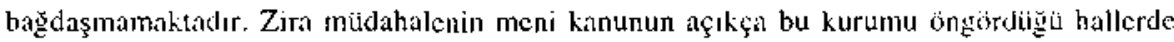
söz kionusu olur (Bydlinski, 11-12).

${ }^{27}$ Kiliı̀n, 82; Bydlinski, 11: Larenz. 42; Yükümlünün irade heyanı yerine gę̣en mahkeme hüknü göriş̧ü için bkz. Larenz 42. Kramer Art.19-20 N.1 16. Schónenberger/Jigggi. Art.1 N.529,530. Ancak once irade beyanınn mahkeme hükmü ile sağlanmlak daha sonra isc sözleşme hükümlerinin yerine getirilmemesi nedeniyle tekrar ifa davası açılması gereksiz bir usulï doğurmaktádır. Bu konuda bkz. Palandt/Heinrichs. Einf.v $\$ 145$ Rdır.8 ve Bydlinski. 13.

Kramer. Art.19-20 N.117; Bydlinski, 24 vd.

${ }^{x / 3}$ Palande/Heinrichs. Einf.v $\$ 145$ Rdnr.8.

Wis Bydlinski. 11; Palandt/Heinrichs, Einfs \$ 145 Rdnr.8; Kramer, Art.19-20 N.113; Hakim BK md.43'e göre tazminatın şeklini ve kapsamın belirler. Bu şekliyle meydana getirilen ikame saklece para ile belirlenmez. Hakim eski durumun yeniden sağlanmás șetilinde (Naturalersatz) bir karar da verebilir bkz. BGE 107 ][ 134, 100 II I42 f. 
zorunluluğunưn gereği mahkeme hükmü ile sağlanmış olur. Tabii ikame de (natural restitution) bir tazminat türüdür.

Bunun dışında hak sahibi ahlaka aykırı bir davranışla kasten zarar verme yasağına dayanarak (BK m.4l/II) tazminat talebinde bulunabilitr" ${ }^{91}$ Bu durumda hak sahibi sözleşme kurma zorunluluğunun bulunduğunu ispatla yükümlüdür ${ }^{92}$. Sözleşmenin esaslı noktalarının kurulma aşamasında belirlenmesi gerekli ise ve bu sözleşme karmaşlk hükümleri içeriyorsa bu durumda hak sahibinin tazminat talebi sınırlanır ${ }^{93}$.

Sözleşme kurmamak suretiyle hak sahibinin kişilik hakkı ihlal edilmişse MK m.24 ve devamında bulunan imkanlar kullanılabilir. Bu anlamda örneğin hakimden sözleşmenin kurulması talep edilebileceği gibi maddi ve manevi tazminat talebinde bulunulabilir.

Talep sahibine sadece zarar vermek kastı ile sözleşme kurulmuyor ve bu davranış ahlaka aykırılık oluşturuyorsa, BK md 41/II'ye göre tazminat talebinde bulunulabilir.

Sözleşmeyi kurma talebinin ređdi hakkın kötiiye kullanılması niteliğinde ise (MK md.2), hakkın kötüye kullanılması hukuka aykırı olduğundan bir zararın doğması halinde $\mathrm{BK}$ m.41'e göre haksız fiilden dolayı bu zararın tazmini talep edilebilir ${ }^{94}$. Ancak bu durumda bazı sorunlu noktalar bulunmaktadır. Sorumluluğun haksız fiile dayandırıldığı hallerde diğer unsurların yanında özellikle kusur ve zarar unsurunun bulunması gerekmektedir. Normal olarak hak sahibinin talebinin yükümlü tarafından kabul edilmemesi halinde hem kusur hem de zarar unsurları gerçekleşmektedir. Ancak, hak sahibinin ileride kurmak istediği bir sözleşmenin reddedilmesi ihtimaline karşı tedbir niteliğinde bulunan dava açması halinde, haksız fuillerin unsurlarından kusur bulunmakta ancak zarar doğmadığmdan tazminata hükmedilmemektedir ${ }^{95}$.

"I Larenz, 42; Kilian. 82; Oftinger, 522 a; bkz. BGE 86 II 371.

${ }^{92}$ Kilian, 82 .

${ }^{93}$ Kramer, Art.19-20 N.117; Schönenberger/Jäggi. Art.1 N.529.

${ }^{4}$ Bydlinski, 10; Canaris, 243; bkz. Palandu/Heinrichs. Einf.$v \$ 145$ Rdnr.7: Kramer. Art .19-20 N.114.

${ }^{\text {95 }}$ Bydlinki, $11 ;$ BGHZ 44, 279. 


\section{KAYNAKÇA}

Aslan, Yılmaz: Rekabet Hukuku, B.2, Bursa 2001.

: Avrupa Topluluğu Rekabet Politikaları Hukuk Dïzeni ve Türk Rekabet Kanun Tasarısı, Ulusłar arası Sempozyum, İstanbul 1993 (Kısaltılmışı: Aslan, Sempozyum).

Badur, Emel: AT Rekabet Hukukunda Hakim Durumun Kötüye Kullanılmàsı, Yayımlanmamı̧ Yüksek Lisans Tezi, Ankara 1998.

Bucher, Eugen: "Drittwirkung der Grundrechte" ?, Überlegungen zu "Streickrecht" und "Drittwirkung" i.S. von BGE 111 II 245-259. SJZ 83 (1987), $37 \mathrm{vd}$.

Bydlinski, Franz: Zu den dogmatischen Grundfragen des Konrahierungszwanges, AcP 180 (1980), 1 vd.

-.-.: Kontrahierungszwang und Anwendung allgemeinen Zivilrecht, JZ 35 (1980), 378 vd. (Kısaltılmışı: Bydlinski. Kontrahierungszwang). $201 \mathrm{vd}$.

Canaris, Claus-Wilhelm: Grundrechte und Privatrecht, AcP 184 (1984).

Dilcher. Hermann : Typenfreiheit und inhaltliche Gestaltungsfreiheit bei Verträgen. NJW 19601040 vd. 1998.

Eren, Fikret: Borçlar Hukuku Genel Hükümler, Cilt.1, Bası 6, İstanbul

Esin, Arif: Rekabet Hukuku, Istanbul 1998.

Gauch. Peter: Der Werkvertrag, Zürich 1996.

Gauch/Schluep/Jäggi: Schweizerisches Obligationenrecht, Allgemeiner Teil, Bd.I, 6.Auflage. Zürich 1995. 1989.

Giger, Hans: Rechtsfolgen norm- und sittenwidriger Verträge, Zürich 
Herzog, R.Nicolos : Der Vorvertrag im schweizerischen und deutchen Schuldrecht, Zürich 1999. $\mathrm{vd}$.

Jäggi, Peter: Bemerkungen zum Fall Seelig, SJZ 50 (1954) Heft 23, 353

Keller, Max/Schöbi, Christian: Allgemeine Lehren des Vertragsrechts, Band.I, Basel und Frankfurt am Main 1982.

Kilian, Wolfgang: Kontrahierungszwang und Zivilrechtssytem, AcP $180(1980) 47 \mathrm{vd}$.

Kramer A.Ernst: Berner Kommentar, Kommentar zum schweizerischen Privatrecht, Bant VII, 1. Abteilung, 2. Teilband, 1. Unterteilband, Art.19-31 OR, Lieferung, 1, Kommentar zu Art.19-20 OR

Kutlu, Meltem: İdare Sözleşmelerinde thale Süreci, İzmir 1997.

Larenz, Karl: Lehrbuch des Schuldrechts, Erster Band, Allgemeiner Teil, München 1987.

Merz, Hanz: Vertrag und Vertragsschluss, Freiburg Schweiz 1988.

Nawiasky, Hans: Das Rechtsverhältnis zwischen den öffentlichen Betrieben und ihren Benützern, SJZ 36 (1940), 197 vd.

Oftinger, Kari: Gesetzgeberische Eingriffe in das Zivilrecht, ZSR 57 (1938), 481 a vd.

Oğuzman, Kemal/Öz Turgut: Borçlar Hukuku Genel Hükümler, İstanbul 1995.

Öz, Gamze: Avrupa Birliği ve Türk Rekabet Hukuku Çerçevesinde "Pazarda Hakim Durumun Kötüye Kullanılması", Yayımlanmamış Doktora Tezi, Ankara 1997.

Palandt, Otto: Bürgerliches Gesetzbuch, 50.Auflage, München 1991.

Ritgen, Klaus,: Vertragsparität und Vertragsferiheit, JZ 3/2002 114 vd. 
Sanlı, Kerem Can: Rekabetin Korunması Hakkındaki Kanun`da öngörülen Yasaklayıcı Hükümler ve bu Hükümlere Aykırı Sözleşme ve Teşebbüs Birliği Kararlarının Geçersizliği. Ankara 2000.

Schluep. Walter: Von der Kontrahierungspflicht der kartellähnlichen Organisation, Wirtschaft und Recht, 21 Jahrgang (1969), $193 \mathrm{vd.}$

Schmith-Salzer, Joachim: Rechtpolitische Grenzen der Zivilrechtlichen Vertragsfreiheit, NJW $1971173 \mathrm{vd}$.

Grundfragen des Vertragsrecht im Zivil- und Verwaltungsrecht, NJW 1971, 5 vd. (Kısaltılmış1: Schmidt-Salzer, (Grundfragen).

: Vertragsfreiheit und Verfassungsrecht, NJW 1970, 8 vd. (Kısaltılmışı: Schmidt-Salzer, (Verțagsfreiheit).

Schönenberger/Jäggi: Kommentar zum Schweizerischen Zivilgesetzbuch, Das Obligationenrecht, Bnd V, 3.Auflage, Zürich, 1968.

Schwabe, Jürgen: Grundrechte und Privatrecht, AcP 185 (1985), I vd.

Schwenzer, Ingeborg: Schweizerisches Obligationenrecht Allgemeinet Teil, Bem 1988.

von Büren, Bruno: Schweizerisches Obligationenrecht, Allgemeiner Teil, Zürich 1964.

Zäch, Roger: Der Einfluss von Verfassungrecht auf das Privatrecht bei der Rechtsanwendung. SJZ 1989 Heft 2, 25 vd. 